\title{
(D) \\ ISSN 1997-5902 \\ Correlation between agronomic and stem borer resistant traits in maize: Implications in selection
}

\author{
Qudrat Olaitan OLOYEDE-KAMIYO \\ Institution: Institute of Agricultural Research and Training, Moor Plantation \\ Address: Maize Improvement Programme, Institute of Agricultural Research and Training, Moor Plantation, PMB \\ 5029, Apata, Ibadan, Nigeria \\ Corresponding author's email address: olaqpublication@yahoo.co.uk, qudratkamiyo@gmail.com \\ Tel: (+234)8060993930
}

Original submitted in on 23rd January 2015. Published online at www.m.elewa.org on $30^{\text {th }}$ June 2015 http://dx.doi.org/10.4314/jab.v90i1.3

\begin{abstract}
Objective: The interrelationship between agronomic and resistant traits of two stem borer species, and its influence on selection was studied in a yellow maize population, DMR ESR-Y, at Ibadan between 2009 and 2010.

Methodology and results: Two hundred and fifty (250) full-sib progenies of the population with three checks were evaluated. Resistant traits had negative correlations with most agronomic traits including grain yield (GY). GY had significant relationship with days to $50 \%$ pollen shed, (DTA) $\left(r g=0.49^{* *}\right)$, plant height $(\mathrm{PH})$ $\left(\mathrm{rg}=0.46^{* *}\right)$ and ear aspect $(\mathrm{EA})\left(\mathrm{rg}=-0.98^{* *}\right)$. Indirect selection of GY via DTA and PH gave gains that were a little lower than direct selection for GY, but they have higher heritability. Indirect selection of stem tunnelling and cob damage through EA would give gains of $150.64 \%$ and $106.94 \%$ respectively.

Conclusion and application of results: This result suggested that either days to $50 \%$ pollen shed or plant height could be considered in selection for stem borer resistance. Ear aspect is another good criterion to consider instead of cob damage and stem tunnelling to hasten selection. The result indicated that breeders selecting for stem borer resistance and high yield could consider plant height, days to $50 \%$ pollen shed, ear aspect and grain yield itself as criteria for selection. In selecting the best genotypes in any crop improvement study therefore, breeders need to consider not only the magnitude of the correlation between pairs of traits, but the desirability of their relationship, ease of measuring the traits, correlated response among the traits, and heritability of the secondary trait selected.
\end{abstract}

Keywords: Correlated responses, heritability, secondary traits, selection, stem borer resistance

\section{INTRODUCTION}

Among insect pests of maize, stem borers are the most damaging and widespread in West and Central Africa. Breeding for host plant resistance has been suggested as the most promising approach for the control of stem borers. This is because it is cheap, compatible with other integrated pest management (IPM) methods and is environmentally safe (Girling, 1980; Gracen, 1989). When breeders attempt to improve any crop variety, they are usually interested in upgrading 
several characters simultaneously. This they consider in selecting the best progenies that will be moved to the next cycle of selection. The extent to which these characters are correlated will therefore influence the breeders' success. In breeding for stem borer resistance for instance, breeders select for low damage or high grain yield under infestation. However, grain yield is greatly influenced by environmental conditions, has complex mode of inheritance, low heritability and may involve several related characters (Stuber and Moll, 1969; Bocanski et al., 2009). Most of the yield components are less complex in inheritance, therefore using other traits that are highly correlated with grain yield and have higher heritability, would make selection of the best progenies more reliable (Vasic et al., 2001; Bekavac et al., 2007, 2008). To improve pest resistance in a maize population, knowledge of the magnitude and direction of relationship between agronomic and resistant traits is important, as this aids selection. Correlation between two unrelated traits may be due to pleiotropy or tight linkage existing between genes controlling them (Falconer, 1981). The degree of correlation arising from pleiotropy expresses the extent to which two

\section{MATERIALS AND METHODS}

A yellow-grained maize population (DMR ESR-Y) sourced from IITA; Ibadan was used in this study. It is resistant to downy mildew and streak disease of maize. Stem borer species used for infestation were the pink stem borer, Sesamia calamistis and the sugarcane borer, Eldana saccharina. Two hundred and fifty full-sib progenies of the population with three checks were evaluated in 2009 and 2010 at Ibadan (Lat. $70^{\circ} 22 \mathrm{~N}$, Long. $03^{\circ} 58 \mathrm{E}$ ) in the derived savanna of Nigeria. A randomized incomplete block design with two replications was used for evaluation. A plot was a single row of $7 \mathrm{~m}$ length divided into two half-row of $3 \mathrm{~m}$ separated by $1 \mathrm{~m}$ in the middle. One of the half-row plots was artificially infested with egg masses of stem borers reared on artificial diet in laboratory, while the characters are influenced by the same gene such that a trait could be selected in place of another. Falconer (1989) stated that if the two characters have low heritability, then the phenotypic correlation is determined chiefly by environmental correlation, but if they have high heritability, then the genetic correlation is more important. Sometimes rapid progress could be made using correlated response to selection. Correlated response suggests that it might sometimes be possible to achieve more rapid progress under selection for a secondary trait than from selection for the desired trait itself. Indirect selection for a trait will only be successful if the secondary character has substantially higher heritability and genetic correlation (Falconer, 1989). Selection for resistance to Mediterranean Corn Borer (MCB) has been reported to positively influence grain yield (Sandoya et al., 2008), and significantly reduced days to silking, plant and ear height, and 100kernel weight, but seedling vigour was increased (Sandoya et al., 2010). This study was therefore carried out to (i) determine the interrelationship between agronomic and stem borer resistant traits, (ii) determine the influence of the relationship on selection.

other half was left as control. Row and hill spacing was $0.75 \mathrm{~m} \times 0.25 \mathrm{~m}$. Two seeds were planted per hill but thinned to one plant per hill at three weeks after planting (WAP) just before infestation to achieve a maximum of 13 plants per plot and a plant density of 53333 plants/ha. An egg mass of $S$. calamistis and $E$. Saccharina containing 30-40 eggs at black head stage was inserted in-between the stem and leaf sheath at 3 WAP, and in-between the developing ear and the stem at silking respectively, on each plant on the infested plot. The stem borer species and their egg mass used for the infestation is shown in Plate1. Agronomic practices such as application of herbicides and fertilizer were carried out as appropriate. 


\section{Oloyede-Kamiyo J. Appl. Biosci. Correlation between agronomic and stem borer resistant traits in maize: Implications in selection}

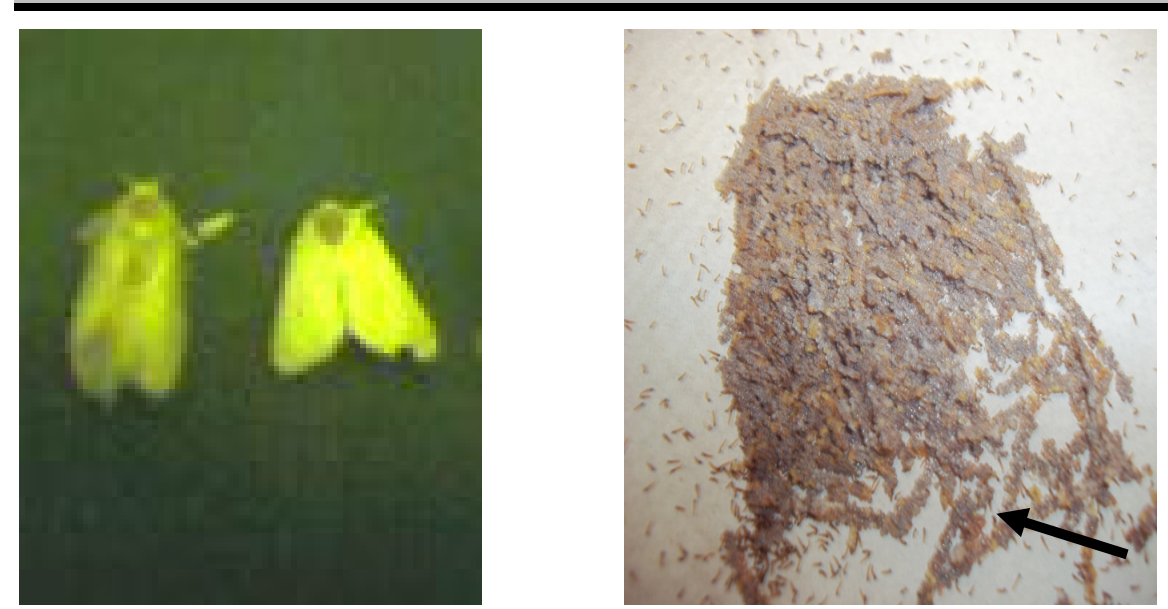

Plate 1. The stem borer species ( Eldana saccharina left, Sesamia calamistis right) and egg mass Sesamia used for artificial infestation of the maize progenies.

Data collection: Data collected included days to $50 \%$ pollen shed estimated as days from planting to the day when half of the plants in a plot had shed pollen. Plant and ear height measured from five competitive plants per plot as distance from base of the plant to base of the tassel and the node bearing the first ear, respectively. Husk cover was rated per plot on a scale of 1-9 based on the tightness of the tips of the husks, where 1 represents long and tight tip, and 9 for very short and loose tip. Ear aspect rated per plot after harvesting based on the neatness and filling of grains on the cobs on a scale of 1-9, 1 representing clean and well-filled ears, and 9 for ears with scanty and rotten or damaged grains. Leaf feeding damage was scored at 3 weeks after infestation (WAI) based on a visual rating on a scale of 1-9 with $1=$ clean plant without leaf defoliation and $9=80-100 \%$ defoliation of the entire leaf area. Stalk breakage was taken as number of broken plants above the first ear and expressed as percentage of plant stand. Number of damaged cobs was also expressed as percentage of number of ears at harvest and taken as Cob damage. Stem tunnelling was taken after harvesting on average of five stalks per plot by splitting the stalks longitudinally and measuring the length tunnelled by the stem borer larvae, and then expressed as a percentage of plant height. Grain yield (t/ha) adjusted to $14 \%$ moisture content, was

\section{RESULTS}

Correlation between agronomic and stem borer resistant traits: Correlation coefficients among traits are presented in Table 1. Days to $50 \%$ pollen shed had positive genotypic correlation with grain yield $\left(0.49^{* *}\right)$. It calculated from ear field weight (FWT) per plot, assuming $80 \%$ shelling percentage as follows:

Grain yield (t/ha) $=$

(FWT $(\mathrm{kg}) /$ plot size $\left.\left(\mathrm{m}^{2}\right)\right) \times[(100-$ Moisture Content) $\mathrm{x} 10,000 \times \mathrm{SP}] / 86 \times 1000$

$\mathrm{SP}=$ Shelling percentage (weight of grains expressed as a percentage of ear weight).

Data analyses: Data on stalk breakage, cob damage, and stem tunnelling were normalized using arcsine transformation for statistical analysis. Data were analyzed using Proc GLM procedure from SAS statistical software Version 9.2 (SAS Institute Inc., 2003). Means and Coefficient of variation (CV) were estimated. Analysis of variance was carried out and heritability estimates was computed from variance components according to Hallauer and Miranda (1988). Phenotypic and genotypic correlation coefficients were computed using variance-covariance matrix and estimates of genetic and phenotypic variances as described by Falconer (1996). Correlated response to selection, which is a measure of indirect selection of traits, was calculated as described by Kearsey and Pooni (1996). Correlated response was expressed as a percentage of predicted response to selection (a measure of direct selection) for each of the traits studied.

was however, negatively correlated with stem tunnelling $\left(r p=-0.21^{*}, r g=-0.32^{*}\right)$ and stalk breakage $(r p=-$ $\left.0.11^{*}, \mathrm{rg}=-0.15^{*}\right)$ although the coefficients were low. Plant height had positive and significant correlation with 
ear height $\left(\mathrm{rp}=0.74^{* *}, \mathrm{rg}=0.76^{* *}\right)$ and grain yield $(\mathrm{r} p=$ $\left.0.32^{*}, \mathrm{rg}=0.46^{* *}\right)$. It also had positive and significant genotypic correlation with ear aspect $\left(0.38^{* \star}\right)$, stalk breakage $\left(0.36^{*}\right)$ and cob damage $\left(0.30^{*}\right)$. Plant height however, had significant negative phenotypic correlation with ear aspect and leaf feeding damage, although with low coefficients. Husk cover rating was significantly correlated with cob damage $\left(\mathrm{rg}=0.75^{*}\right)$.

Table 1: Phenotypic (above diagonal) and genotypic (below diagonal) correlation coefficients of 10 traits of DMR ESR-Y maize population evaluated under stem borer infested condition at Ibadan between 2009 and 2010.

\begin{tabular}{|c|c|c|c|c|c|c|c|c|c|c|}
\hline Traits & 1 & 2 & 3 & 4 & 5 & 6 & 7 & 8 & 9 & 10 \\
\hline $\begin{array}{l}1 \text { Days to } 50 \% \\
\text { pollen shed }\end{array}$ & & $-0.16^{*}$ & -0.02 & $-0.11^{*}$ & 0.00 & -0.04 & $-0.21^{*}$ & $-0.11^{*}$ & -0.01 & $0.10^{*}$ \\
\hline $\begin{array}{l}2 \text { Plant height } \\
\text { (cm) }\end{array}$ & $0.19^{*}$ & & $0.74^{\star \star}$ & -0.04 & $-0.17^{*}$ & $0.32^{*}$ & 0.01 & $0.09^{*}$ & -0.06 & $-0.09^{*}$ \\
\hline $\begin{array}{l}3 \text { Ear height } \\
\text { (cm) }\end{array}$ & $0.16^{*}$ & $0.76^{* *}$ & & $-0.08^{*}$ & $-0.18^{*}$ & $0.20^{*}$ & 0.01 & $0.11^{*}$ & -0.05 & -0.01 \\
\hline $\begin{array}{l}4 \text { Husk cover } \\
\text { rating }\end{array}$ & -0.01 & $-0.21^{*}$ & $-0.34^{*}$ & & $0.11^{*}$ & -0.03 & 0.07 & -0.02 & $0.08^{*}$ & 0.02 \\
\hline 5 Ear aspect & $-0.73^{\star \star}$ & $0.38^{\star *}$ & $-0.23^{*}$ & $0.89^{\star \star}$ & & $-0.39^{\star \star}$ & $0.22^{*}$ & -0.02 & $0.33^{*}$ & $0.13^{*}$ \\
\hline $\begin{array}{l}6 \text { Grain Yield } \\
\text { (t/ha) }\end{array}$ & $0.49^{* \star}$ & $0.46^{* *}$ & $0.20^{*}$ & -0.18 & $-0.98^{\star *}$ & & $-0.20^{*}$ & -0.04 & $-0.24^{*}$ & $-0.24^{*}$ \\
\hline $\begin{array}{l}7 \text { Stem tunnelling } \\
(\%)\end{array}$ & $-0.32^{*}$ & -0.03 & -0.12 & -0.21 & $0.70^{* \star}$ & $-0.52^{*}$ & & 0.05 & $0.16^{*}$ & $0.20^{*}$ \\
\hline $\begin{array}{l}8 \text { Stalk } \\
\text { breakages (\%) }\end{array}$ & $-0.15^{*}$ & $0.36^{*}$ & $0.38^{* *}$ & 0.05 & -0.07 & 0.15 & $0.30^{*}$ & & $0.15^{*}$ & 0.07 \\
\hline $\begin{array}{l}9 \text { Cob damage } \\
(\%)\end{array}$ & -0.03 & $0.30^{*}$ & -0.07 & $0.75^{* \star}$ & $0.91^{* *}$ & -0.08 & 0.10 & $0.40^{*}$ & & $0.22^{*}$ \\
\hline $\begin{array}{l}10 \text { Leaf feeding } \\
\text { damage }\end{array}$ & $t$ & $t$ & $t$ & $t$ & $\dagger$ & 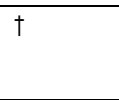 & $\dagger$ & $\dagger$ & $t$ & \\
\hline
\end{tabular}

*, **: Significant at 0.05 and 0.01 level of probability respectively

tNot estimated due to negative genetic variance

Ear aspect had significant positive relationship with stem tunnelling ( $\mathrm{rp}=0.22^{*}, \mathrm{rg}=0.70^{* *}$ ) and cob damage $\left(r p=0.33^{*}, r g=0.91^{* *}\right)$. Grain yield had positive and significant genotypic correlations with most agronomic traits. It was however, negatively correlated with the resistant traits with the highest genotypic correlation being between grain yield and stem tunnelling $\left(-0.52^{\star}\right)$. Positive relationship existed among the resistant traits, the highest being between cob damage and stalk breakage $\left(\mathrm{rg}=0.40^{\star}\right)$ followed by stalk breakage and stem tunnelling $\left(\mathrm{rg}=0.30^{*}\right)$. Genotypic correlation was not estimated for leaf feeding damage because of negative genetic variance. Generally, phenotypic correlations were lower than their corresponding genotypic correlations for most of the traits studied.
Heritability estimates and correlated responses of the agronomic and resistant traits: Means, CVs and narrow-sense heritability estimates of the agronomic and resistant traits are shown in Table 2. CVs were moderate for most of the traits except stem tunnelling, stalk breakage and cob damage among the resistant traits. Heritability estimates were moderate to high for most of the agronomic traits under infestation except for grain yield. The highest heritability estimate was recorded in husk cover rating (64.93\%), followed by ear height $(54.13 \%)$. Heritability estimates were lower among the resistant traits. The highest was recorded in cob damage $(40.10 \%)$ followed by stalk breakage $(26.18 \%)$. The least heritability was recorded in leaf feeding damage $(6.72 \%)$. Mean of stem tunnelling was the least among resistant traits. 
Table 2: Mean \pm S.E, CV and Narrow-Sense Heritability (NSH) estimates for 10 traits of DMR ESR-Y maize population evaluated under stem borer infested condition at Ibadan between 2009 and 2010.

\begin{tabular}{lccc}
\hline Traits & Means \pm S.E & CV (\%) & NSH (\%) \pm S.E \\
\hline Days to 50 \% pollen shed & $48.8 \pm 0.99$ & 2.9 & $37.97 \pm 0.14$ \\
Plant height $(\mathrm{cm})$ & $175.4 \pm 8.28$ & 6.7 & $45.28 \pm 0.17$ \\
Ear height $(\mathrm{cm})$ & $89.6 \pm 5.65$ & 8.9 & $54.13 \pm 0.17$ \\
Husk cover rating & $3.3 \pm 0.58$ & 24.7 & $64.93 \pm 0.23$ \\
Ear aspect & $5.3 \pm 0.87$ & 23.1 & $46.03 \pm 0.33$ \\
Grain Yield (t/ha) & $3.2 \pm 0.61$ & 27.0 & $10.47 \pm 0.12$ \\
Stem tunnelling (\%) & $4.4 \pm 2.46$ & 78.6 & $8.12 \pm 0.18$ \\
Stalk breakage (\%) & $19.9 \pm 10.75$ & 76.5 & $26.18 \pm 0.15$ \\
Cob damage (\%) & $43.9 \pm 14.88$ & 47.9 & $40.10 \pm 0.29$ \\
Leaf feeding damage & $4.7 \pm 0.91$ & 27.6 & $6.72 \pm 0.39$ \\
\hline
\end{tabular}

Table 3: Correlated responses (expressed as percentage of expected gain) to selection for 10 traits of DMR ESR-Y maize population evaluated under stem borer infested condition at Ibadan in 2009 and 2010

\begin{tabular}{|c|c|c|c|c|c|c|c|c|c|c|}
\hline Traits & 1 & 2 & 3 & 4 & 5 & 6 & 7 & 8 & 9 & 10 \\
\hline $\begin{array}{l}1 \text { Grain Yield } \\
\text { (t/ha) }\end{array}$ & 100.00 & 35.71 & 40.23 & 8.79 & -47.29 & -7.25 & $t$ & -53.37 & 9.77 & -1.53 \\
\hline $\begin{array}{l}2 \text { Days to } 50 \% \\
\text { pollen shed }\end{array}$ & 99.26 & 100.00 & 86.35 & $\begin{array}{l}-13.39 \\
\end{array}$ & -67.09 & -0.77 & $t$ & -62.54 & -18.61 & -2.91 \\
\hline $\begin{array}{l}3 \text { Plant height } \\
(\mathrm{cm})\end{array}$ & 96.46 & 20.64 & 100.00 & 69.48 & 38.14 & -17.60 & $t$ & -6.40 & 48.78 & 31.82 \\
\hline $\begin{array}{l}4 \text { Ear height } \\
(\mathrm{cm})\end{array}$ & 43.99 & -19.09 & 83.09 & 100.00 & -25.24 & -31.15 & $t$ & -28.00 & 56.30 & -8.12 \\
\hline 5 Ear aspect & -198.76 & -80.31 & 38.31 & -21.20 & 100.00 & 84.49 & + & 150.64 & -9.56 & 106.94 \\
\hline $\begin{array}{l}6 \text { Husk cover } \\
\text { rating }\end{array}$ & -43.36 & -1.31 & -25.14 & -37.22 & 120.18 & 100.00 & $\dagger$ & -53.67 & 8.11 & 95.25 \\
\hline $\begin{array}{l}7 \text { Leaf feeding } \\
\text { damage }\end{array}$ & $\dagger$ & $t$ & $\dagger$ & $t$ & $\dagger$ & $\dagger$ & $t$ & $\dagger$ & $\dagger$ & $\dagger$ \\
\hline $\begin{array}{l}8 \text { Stem } \\
\text { tunnelling (\%) }\end{array}$ & -44.30 & -3.23 & -5.08 & 20.13 & 29.75 & -7.45 & $\dagger$ & 100.00 & 21.05 & 4.49 \\
\hline $\begin{array}{l}9 \text { Stalk } \\
\text { breakage (\%) }\end{array}$ & 22.94 & -12.44 & 27.37 & 26.42 & -5.34 & 3.19 & $t$ & 43.08 & 100.00 & 48.23 \\
\hline $\begin{array}{l}10 \text { Cob } \\
\text { damage (\%) }\end{array}$ & -5.68 & -3.08 & 28.23 & -6.02 & 94.44 & 59.14 & $t$ & 20.09 & 54.63 & 100.00 \\
\hline
\end{tabular}

Table 3 presents the correlated response, which is a measure of indirect selection. Direct selection for most of the traits would be better than indirect selection through any other trait except in few instances. An example of a situation where indirect selection might be more effective is in selecting for ear aspect through husk cover rating $(120.18 \%)$ which would give a gain of $20.18 \%$ above the gain attainable through direct selection for ear aspect. In addition, selection for stem tunnelling and cob damage through ear aspect would give response of $150.64 \%$ and $106.94 \%$, respectively. Direct selection for grain yield seems to be more effective than indirect selection through any other trait. Selection for grain yield through plant height and days to $50 \%$ pollen shed would give a gain of $96.46 \%$ and $99.26 \%$, a little below the gain attainable through 


\section{DISCUSSION}

Knowledge of the magnitude and direction of relationship between agronomic and stem borer resistant traits is important in improvement of a maize population for stem borer resistance as this aids selection. For effective selection of traits, heritability also plays an important role. This is because, the degree to which genotypic values of superior parents are transmitted to the offspring depend on the heritability of the traits selected (Hallauer and Miranda, 1988). Falconer (1989) stated that if the two characters have low heritability, then the phenotypic correlation is determined chiefly by environmental correlation, but if they have high heritability, then the genetic correlation is more important. The high heritability for cob damage and ear aspect, husk cover rating and ear aspect, and plant and ear height contributed to the high genotypic correlations between these pairs of traits. The high correlation suggests that the two traits of each pair are influenced by the same gene, and that either trait of the pair could be selected with equal effect according to Falconer (1981). Days to $50 \%$ pollen shed being positively correlated with grain yield, but negatively correlated with stem tunnelling, as well as the strong negative correlation between stem tunnelling and grain yield, suggests that late-maturing plants tend to have more yields and reduced stem tunnelling. This is an indication that reduced tunnelling might be an important trait to select for high grain yield. This corroborates the reports of Ajala and Saxena (1994) and Odiyi (2007). Plant height being positively correlated with stalk breakage suggests that tall plants tend to break easily. The strong positive correlation between husk cover rating and cob damage is expected. This is because, when the husk cover is very tight, it will be difficult for the larvae of Eldana to penetrate and cause damage to the developing cob. The negative correlation between grain yield and resistant traits in this maize population suggests possible improvement for resistance to stem borers with increased grain yield. Similar results were reported by Ajala (1994) and Ajala and Saxena (1994) for the spotted stem borer and by Gounou et al. (1994) for stem and ear borers. The positive relationship observed among resistant traits indicates that selection for reduced levels of damage caused by one borer species would have positive impact on damage caused by another borer, resulting in greater progress in breeding for combined resistance to both borer species
(Ajala et al., 2008). When improving a plant, breeders rarely select a trait singly but include some other related traits. The choice of those other traits to include will depend on their association with the desired trait, as well as level of gain that will be achieved by selecting such traits. Correlated response to selection suggests that it might sometimes be possible to achieve more rapid progress under selection for a secondary trait than from selecting for the desired trait itself (Falconer, 1989). If genetic association exists between two traits, selection for one trait will cause an indirect change in the mean of the other trait. The extent of the change will however depend on the degree of association between the two traits (Hallauer and Miranda, 1988). Nonetheless, indirect selection for a trait will only be successful if the secondary character has substantially higher heritability than the desired trait and genetic correlation between the two traits is high (Falconer, 1989). The result of the present study indicates that husk cover rating could be selected for ear aspect. This is not unconnected with the higher heritability for husk cover than ear aspect and the strong genotypic correlation between the two traits. Ear aspect also has higher indirect response than selecting for stem tunnelling or cob damage singly; hence, it could be selected in place of the two traits. Similar observation was made by Odiyi (2007). Grain yield could also be selected through plant height, although the correlated response is a little below direct selection of grain yield itself. This is because strong genotypic correlation existed between them and the heritability of plant height is higher. However, the strong positive genotypic correlation between them could impede selection because tall plants are liable to lodging and are therefore not desirable to farmers. Breeders then need to set standard for the height desired among the promising progenies. Indirect selection of grain yield via days to $50 \%$ pollen shed was also high although a little lower than direct selection of grain yield itself but with higher heritability. Therefore, either plant height or days to $50 \%$ pollen shed could also be involved as a criterion in selection, but with grain yield itself. Selection for days to flowering would result in reduction in stem tunnelling and stalk breakage, as also observed by Odiyi (2007). Selection for increased grain yield would cause reduction in stem tunnelling and cob damage. Sandoya et al. (2008) observed that selection for 
resistance to Mediterranean Corn Borer (MCB) positively influenced grain yield. Sandoya et al. (2010) however reported that selection for resistance to MCB significantly reduced days to silking, plant and ear height, and 100-kernel weight, but seedling vigour was

\section{CONCLUSION}

In selecting the best progeny in any crop improvement study therefore, breeders need to consider not only the magnitude of the correlation between traits, but the desirability of the association, ease of measuring the desired trait, response of the desired trait while selecting another secondary trait, as well as the increased. If a resistant trait is to be included among the selection criteria, stem tunnelling could be considered because of its higher response than other resistant traits, and its strong negative correlation with grain yield.

heritability of the secondary trait. The results in this present study indicated that breeders selecting for stem borer resistance and high yield could consider plant height, days to $50 \%$ pollen shed, ear aspect and grain yield itself as criteria for selection.

\section{ACKNOWLEDGEMENTS}

The author thanks the International Institute of Tropical Agriculture (IITA), Ibadan for providing all the necessary materials needed for this project.

\section{REFERENCES}

Ajala SO, 1994. Maize (Zea mays L.) Stem borer (Chilo partellus Swinehoe) infestation/damage and plant resistance. Maydica 39: 203-205.

Ajala SO, Odiyi AC, The C, Olaoye G, 2008. Population cross diallel of maize genotypes with varying levels of resistance to the pink stem borer (Sesamia calamistis: Hampson) and the Sugarcane borer (Eldana saccharina: Walker). Maydica 53: 79-86.

Ajala SO and Saxena KN, 1994. Interrelationship among Chilo partellus (Swinhoe) damage parameters and their contribution to grain yield reduction in maize (Zea mays L.). Applied Entomology and Zoology 29 (4): 469-476.

Bekavac G, Purar B, Jockovic D, 2008. Relationship between line per se and testcross performance for agronomic traits in two broadbased populations of maize. Euphytica 162: 363-369.

Bekavac G, Purar B, Stojakovic M, Jockovic D, Ivanovic $M$, Nastasic A, 2007. Genetic analysis of staygreen traits in broad-based maize populations. Cereal Research Communications 35 (1): $31-$ 41.

Bocanski J, Sreckov Z, Nastasic A, 2009. Genetic and phenotypic relationship between grain yield and components of grain yield of maize (Zea mays L.). Genetika 41 (2): 145-154

Falconer DS, 1981. Introduction to quantitative genetics. 2nd edition. New York: Longman Inc. 294-296.

Falconer DS, 1989. Introduction to quantitative genetics. $3^{\text {rd }}$ Edition. New York: Longman Inc. 438pp.

Falconer DS, 1996. Introduction to quantitative genetics. $4^{\text {th }}$ Edition. New York: Benjamin Cummings, Longman Inc.

Girling DJ, 1980. Eldana sacharinna as crop pest in Ghana. Tropical pest management 26: 152157.

Gounou, SF, Schulthess T, Shanower WNO, Hammond $\mathrm{H}$, Braiima AR, Cudjoe R, Adjakloe KK, Antwi \& Olaleye I, 1994. Stem borer and Ear borers of maize in Nigeria. Plant health Management Research Monograph, N.4 IITA, Ibadan. 25.

Gracen VE, 1989. Breeding for resistance to the European corn borer. In: CIMMYT, 1989. Towards insect resistance maize for the 3 rd World. Proceedings of International Symposium, Methodologies for Developing Host Plant Resistance to Maize Insects. Pp. 203-206. 9-14th March 1987. Mexico City: El Bataan Mexico CIMMYT.

Hallauer AR and Miranda JB Eds, 1988. Heredity variance: Mating designs. Quantitative genetics in maize breeding. 2nd edition. USA: lowa State Univ. Press, Ames. 45-114.

Kearsey MJ and Pooni HS, 1996. The genetical analysis of quantitative traits. London SEI 8HN, UK: Chapman and Hall, 2-6 Boundary Row. 381pp. 
Odiyi AC, 2007. Relationship between stem borer resistance traits and grain yield reduction in maize: Correlations, Path analysis and Correlation responses to selection. Agricultural Journal 2 (2): 337-342.

Sandoya G, Butrón A, Alvarez A, Ordás A, Malvar RA, 2008. Direct response of a maize synthetic to recurrent selection for resistance to stem borers. Crop Science 48: 113-118.

Sandoya G, Butron A, Santiago R, Alvarez A, Malvar RA, 2010. Indirect response to selection for improving resistance to the Mediterranean Corn Borer (Sesamia nonagrioides Lef) in maize. Euphytica 176 (2): 231-237.
SAS Institute Inc., 2003. SAS/STAT user's guide, version 9.1.3. SAS Institute Inc., Cary, NC, USA.

Stuber CW and Moll RH, 1969. Epistasis in Maize 1: $F_{1}$ hybrid and their $S_{1}$ progeny. Crop Science 9 : 124-127.

Vasic N, Ivanovic M, Peternelli $L$, Ockovic JD, Stojakovic M, Bocanski J, 2001. Genetic relationships between grain yield and yield components in a synthetic population and their implications in selection. Acta Agronomica Hungarica 49 (4): 337-342. 